\title{
Field Applications for Color Enhancement of 'Valencia' Oranges while Reducing
} Leaf Abscission

\author{
Farag K.M. ${ }^{1}$, Ahmed S. Elsabagh ${ }^{1}$, Neven M. N. Nagy ${ }^{1}$, Omnia M. Mekkawy ${ }^{2}$ \\ ${ }^{1}$ Department of Horticulture (Pomology), Faculty of Agric., Damanhour. Univ., Egypt \\ ${ }^{2}$ Hort. Res. Institute, Agric. Res. Center, Giza, Egypt.
}

Received: 09 Oct. 2019 / Accepted 14 Nov. 2019/Publication date: 30 Nov. 2019

\begin{abstract}
The present study was performed during the two successive seasons 2014 and 2015 using 'Valencia' orange trees. Trees were 7 years old, budded on 'Volkamer' lemon rootstock. Thirty-Two uniform trees were selected for the investigation. The soil texture was sandy and the drip irrigation system was adopted. This study was conducted to enhance the coloration of 'Valencia' orange fruits by using Ethrel before harvest in a new formulation to mitigate its damaging effects on abscission of leaves and fruits. Treatments included water as the control, Lisophos (LPE) at $200 \mathrm{ppm}$, Ethrel at 500 ppm alone or in a combination with LPE and LPE followed by (24 hours later) Ethrel. Meanwhile, calcium acetate were applied individually at $300 \mathrm{ppm}$ or mixed with Ethrel in addition to calcium acetate preceded Ethrel by 24 hours. Top film at $0.05(\mathrm{v} / \mathrm{v})$ was added to all treatments and the trees were sprayed in 15, 22 and 29 January, respectively during the two seasons of study. The results proved that the treatment with Ethrel alone resulted in the highest percentage of leaf abscission. The percentage of leaf abscission was over $50 \%$. However, treatment with either calcium acetate mixed with Ethrel, calcium acetate followed by Ethrel, Lisophos mixed with Ethrel or Lisophos followed by Ethrel reduced the percentage of leaf abscission compared to Ethrel alone. Meanwhile, calcium acetate when preceded the application of Ethrel or when Lisophos was followed by Ethrel were able to alleviate the damage on leaf abscission, especially at the period between the third spray and the harvest time. An enormous leaf abscission occurred following the third spray with many treatments, especially with the sole application of Ethrel that resulted in about $86 \%$ leaf abscission. However, the application of Ethrel three times on the same labeled branch resulted in a very drastic leaf abscission that ranged between 84 and $91 \%$ for the two seasons, respectively. On the other hand, calcium acetate followed by Ethrel or calcium mixed with Ethrel treatments had a significantly increase fruit length, fruit diameter, fruit size, total sugers and carotene as compared with the control but caused a decrease in chlorophyll $\mathrm{a}$ and $\mathrm{b}$ contents. In conclusion, research emphasized that using Ethrel before harvest in a new technique to mitigate its damaging effects on abscission of leaves and fruits especially when sprayed after LPE or calcium acetate 24 hours.
\end{abstract}

Keywords: 'Valencia' oranges, Field application, Coloration, Carotene, Ethrel, LPE, Calcium acetate, Leaf abscission.

\section{Introduction}

Citrus (Citrus sinensis L.) is an important fruit crop in tropical and subtropical countries. The citrus plants belong to the family Rutaceae which includes fruits such as orange, mandarin, lime, lemon, sour orange, and grapefruit are considered as a well-known promising source of multiple beneficial nutrients for human beings (Rafiq et al., 2018). Meanwhile, citrus is one of the most important fruits in the world for containing some useful elements for human health. Some species of the citrus represents a source for antioxidants that act against heart diseases, cancer, inflammation, viral, bacterial and fungal activity. Citrus fruit has a high contents of flavonoids, terpenes, phytonutrients and range of phenolic compounds, vitamin $\mathrm{C}$ and carotenoids. These biochemical compounds were found in fruit rag, juice, seed and peel (Ahmed and Azmat, 2019). Generally, citrus fruits are peeled and eaten fresh in two edible stages (mature green and mature yellow), squeezed for its juice or dehydrated orange juice (orange juice powder) and the peel is a rich source of essential oils which are used to prepare many types of medicines and cosmetics. (Enejoh et al., 2015).

Global production of citrus fruit had significantly increase during the past few years. Citrus fruit production of the world increased from 116.2 million tonnes in 2008 to 124.3 million tonnes in 2016.

Corresponding Author: Farag K.M., Department of Horticulture (Pomology), Faculty of Agric., Damanhour. Univ., Egypt 
Egypt citrus fruit production increased from 3.3 million tonnes in 2008 to 4.9 million tonnes in 2016 (FAOSTAT, 2017).

Cultivating citrus in the desert faces many problems that affect the quality of fruits such as wind injury, frost damage, sunburn, sunscald, cold injury, puffiness, creasing, split fruit, oleocellosis, rind stipple of grapefruit, peteca in lemon, fruit drop, in addition to various abiotic stresses such as heat, salt, and drought.

There have been a lot of previous research to solve these problems, but there is a lack of the amount of information available in previous research to solve these problems. One of these problems is the coloration of citrus fruits since the fruit color is one of the most important external factors that affect fruit quality. The appearance of the fruit significantly influences the consumer's preference when purchasing citrus fruit. In general, the consumer prefers a deep orange-colored fruit (Krajewski, 1997).

Attempts were made to solve this problem using plant growth regulators such as using ethylene releasing compounds. Ethylene has been considered a plant growth regulator of ripening and senescence. Mature citrus fruits release very low amounts of ethylene although they respond to exogenous ethylene by accelerating color break through both chlorophyll degradation and carotenoid synthesis. The exogenous ethylene certainly accelerates chlorophyll disappearance and increases chlorophyllase activity which reflects faster chlorophyll degradation in the peel (Fujii et al., 2007). On the other hand, leaf abscission was greatly affected by ethephon which jeopardized the floral induction process and next season crop (Liegeois et al., 1995). When ethephon was applied at 480 ppm on trees, it improved rind color development by reducing chlorophyll levels and increased starch levels in the plastids but it caused leaf abscission (Alferez and Burns, 2006).

Leaf abscission was one of the problems of Ethrel or ethephon application. Thus, there has been a great need to face this problem and to enhance fruit colors by employing safe compounds such as Lysophosphatidylethanolamine (LPE) and calcium acetate.

The combined treatment of LPE at $800 \mathrm{ppm}$ followed by Ethrel at $50 \mathrm{ppm}$ was applied to reduce fruit abscission and electrolyte leakage while improve fruit quality especially enhance coloration as shown by the consistent increase of anthocyanin and carotene contents. Meanwhile, this combination of LPE when preceded Ethrel was still able to prolong the shelf life of treated 'Keitt' mangoes (Farag and Nagy, 2018).

In addition, adding calcium acetate to ethephon solution almost completely prevented fruit drop and defoliation of "Ponkan" citrus trees with hardly any adverse effect on coloration. Moreover, chelated calcium at $84 \mathrm{ppm}$ was also reported to mitigate the adverse effect of ethephon applied at 300 ppm (Iwahori and Oohata, 1981).

Thus, the objectives of this study were to enhance citrus fruit content of carotene at the early harvest by using a practical and safe mean while minimizing defoliation and to avoid the problems associated with drastic leaf abscission such as sunburn, sunscald and depletion of stored food. Moreover, to provide citrus growers with feasible treatments to de-green their fruits and achieve their goal of early harvest of well-colored fruits. The study also aimed to assess the efficacy of Ethrel alone or in a formulation on various citrus fruit quality parameters.

\section{Materials and Methods}

The present study was performed during the two successive seasons 2014 and 2015 using 'Valencia' orange trees (Citrus sinensis L.). Trees were 7 years old, spaced at $4 \times 5 \mathrm{~m}$ and budded on 'Volkamer' lemon rootstock (Citrus volkamariana). The trees were grown in the Agricultural Research Center orchard at Nubariyah region, Beheira Governorate, Egypt. Soil texture was sandy and drip irrigation system was adopted. Thirty-two uniform trees have been receiving standard agricultural practices and free from physiological disorders or visible pathological problems were selected for the investigation.

\section{At field work:}

Field treatments: Eight treatments were applied to 32 trees randomly. Four replications were used for each treatment, one tree represented one replication and the treatments were applied to the northern half of each tree. These treatments included: 
1- Water as the control.

2- Lysophosphatidylethanolamine (LPE) at $200 \mathrm{ppm}$.

3- Ethrel at $500 \mathrm{ppm}$.

4- Lysophosphatidylethanolamine (LPE) at $200 \mathrm{ppm}+$ Ethrel at $500 \mathrm{ppm}$.

5- Lysophosphatidylethanolamine (LPE) at $200 \mathrm{ppm}$ (24 hours ahead) then Ethrel at $500 \mathrm{ppm}$.

6- Calcium acetate at $300 \mathrm{ppm}$.

7- Calcium acetate at $300 \mathrm{ppm}+$ Ethrel at $500 \mathrm{ppm}$.

8- Calcium acetate at $300 \mathrm{ppm}$ (24 hours ahead) then Ethrel at $500 \mathrm{ppm}$.

Trees were sprayed in January 15, 22 and 29 during 2014 and 2015 seasons, respectively. The non-ionic surfactant Top film at $0.05 \%(\mathrm{v} / \mathrm{v})$ was added to all treatments to reduce the surface tension and to increase the contact angle of sprayed droplets. Trees were sprayed to the run off using a hand sprayer.

\section{Assessment of leaf abscission:}

Five branches $(1.5 \mathrm{~cm}$ in diameter) located at the northern half of each tree were labeled, and their leaves had been counted four times. Once before each spray and once before sampling (one month after the last spray) then leaf abscission was calculated as a percentage of the initial number.

The following equation was used:-

$$
\text { Leaf abscission }(\%)=\frac{\text { Initial leaves number }- \text { Final leaves number }}{\text { Initial leaves number }} \times 100
$$

\section{At laboratory work:}

\section{Fruit quality parameters:}

Five fruits per each treated tree were randomly picked after one month of the last treatment (Feb. 28 ) and exposed to some physical and chemical assessment as shown.

\section{Physical characteristics:}

The average weight of five fruits was utilized as a representative sample for each replication (tree) by using a digital analytical balance to determined fruit weight $(\mathrm{gm})$. Fruit length $(\mathrm{cm})$ was determined by using a Vernier caliper and average fruit length of five fruits was calculated. Fruit diameter $(\mathrm{cm})$ at the tropic was also measured of fruit by using a Vernier caliper and average of five fruits was recorded. Fruit size $\left(\mathrm{cm}^{3}\right)$ was measured by using a graduated cylinder and average volume of five fruits was recorded. Reg weight and Flesh weight (gm) were measured by utilizing a digital analytical balance.

\section{Chemical characteristics:}

The percentage of total soluble solids (T.S.S) was checked in orange fruit juice using a pocket refractometer. Acidity content (\%) was measured as gm citric acid (dominant acid in orange fruits) per $100 \mathrm{ml}$ juice and calculated using the method described by A.O.A.C. (1985). Vitamin C content as $\mathrm{mg} \mathrm{L}$-ascorbic acid per $100 \mathrm{ml}$ orange juice was determined according to the procedure of A.O.A.C. (1985). The percentage of total sugars were extracted and measured by using the phenol-sulfuric acid method (Smith, 1956), and the concentration was calculated from a standard curve of glucose. Chlorophylls a, b and Beta-Carotene content were extracted, measured and calculated as $(\mathrm{mg} / 100 \mathrm{ml})$ according to Lichtenthaler and Wellburn (1985).

\section{Statistical analysis:}

The data of leaf drop was laid out as split plot analysis in randomized complete blocks design (RCBD) where eight treatments presented the main plot factors as treatments and four times were devoted as sub plot, three of them as spraying time and one of them as the picking time. The remaining data of this study was arranged in a randomized complete blocks design (RCBD). All obtained data of the measured parameters were subjected to computerized statistical analysis using 
COSTAT programe for analysis of variance (ANOVA) and means of treatments were compared using LSD at 0.05 level of possibility (Snedecor and Cochran, 1980).

\section{Results}

The effect of preharvest applied treatments on leaf abscission (\%) during 2014 and 2015 seasons:

The influence of various applied treatments on leaf abscission before harvest was illustrated in Tables $(1-2)$. The data revealed that the highest abscission occurred with the application of Ethrel alone as it exceeded $50 \%$ of the sprayed leaves on the branch in both seasons. Such a high rate of leaf drop was reduced when calcium acetate was mixed with Ethrel or if calcium acetate treatment preceded the application of Ethrel. However, calcium acetate treatment alone was able to significantly reduce leaf drop as compared with the application of Ethrel alone. On the other hand, the application of Lisophos alone resulted in similar leaf drop to that found in the control in consistent manner, in both seasons. Meanwhile, when Ethrel treatment followed Lisophos application, there was a significant reduction in leaf abscission when compared with the application of Ethrel alone in the two seasons. In other words, the application of Lisophos in advance was able to mitigate the adverse effect of Ethrel on leaf drop. Even when both Lisophos and Ethrel were mixed before spraying, there was non significant reduction in leaf drop following the application as compared with the sole application of Ethrel. In addition, Lisophos alone, or the control had a similar influence on leaf drop in the two seasons.

\section{The effect of spraying time on leaf abscission (\%) during the two seasons 2014 and 2015:}

The data in Tables (1-2) showed the influence of the time factor on leaf abscission of 'Valencia' orange trees in response to the number of applications, regardless the treatments, during the two seasons 2014 and 2015. The data revealed that such percentage of leaf drop did not significantly change between the first and the second spray, while it was increased between the second and the third spray in a consistent manner in both seasons. However, leaf abscission was significantly increased between the third spray and before the harvest time. Consequently, there was a significant increase in leaf abscission when comparing the first time and the harvest time in both seasons. The magnitude of such abscission reached over 40 and 50\% in the two seasons 2014 and 2015 respectively.

The effect of interaction between preharvest applied treatments and the time factor on leaf abscission (\%) of 'Valencia' orange trees during 2014 season:

The data shown in Table 1 illustrated the effect of the interaction between various applied treatments and the time factor on the percentage of leaf abscission in 'Valencia' orange trees during the 2014 season. The data indicated that the greatest magnitude of leaf abscission was obtained with the application of Ethrel. However, the formulation of Ethrel that included calcium acetate had a comparable percentage of abscission to that found with Ethrel alone between the third and the harvest time of assessment. In a similar manner, mixing Lisophos with Ethrel did not mitigate the adverse effect of Ethrel on leaf abscission during the same above period. However, when the Lisophos treatment preceded Ethrel application, it was able to alleviate the damage on leaf abscission after the second and the third spray till harvest time. Meanwhile, the sole application of Lisophos resulted in a similar percentage of leaf abscission to that obtained by the control over the duration of assessments. That was the trend when calcium acetate application preceded Ethrel treatment since there was a significant reduction of leaf abscission after the three applications comparing with just applying Ethrel alone.

The effect of interaction between preharvest applied treatments and the time factor on leaf abscission (\%) of 'Valencia' orange trees during 2015 season:

In the second season, similar trend of results was obtained following the third spray (Table 2) since the highest leaf abscission was found with Ethrel alone followed by calcium acetate alone. However, in this season, an enormous leaf abscission accured following the third spray with many treatments especially with the sole application of Ethrel that resulted in about $86 \%$ leaf abscission. The magnitude of leaf abscission was greater than the first season. However, following the third 
Table 1: The effect of the preharvest treatments, the time factor and their interaction between them on leaf abscission (\%) of 'Valencia' treated orange trees during 2014 season:

\begin{tabular}{|c|c|c|c|c|c|c|c|c|c|c|}
\hline \multirow{2}{*}{$\begin{array}{l}\text { Treatments } \\
\text { Control }\end{array}$} & \multicolumn{2}{|c|}{ After first spray } & \multicolumn{2}{|c|}{ After second spray } & \multicolumn{2}{|c|}{ After third spray } & \multicolumn{2}{|c|}{$\begin{array}{c}\text { Before first spray } \\
\text { until harvest }\end{array}$} & \multicolumn{2}{|r|}{ Mean } \\
\hline & 8.84 & fg* & 1.14 & $\mathrm{~g}$ & 4.76 & fg & 14.33 & fg & 7.27 & $\mathrm{~d}$ \\
\hline Lisophos & 1.49 & $\mathrm{~g}$ & 7.80 & fg & 10.52 & fg & 18.39 & efg & 9.55 & $\mathrm{~d}$ \\
\hline Ethrel & 19.24 & efg & 45.05 & bcde & 60.58 & $\mathrm{abc}$ & 84.13 & $\mathrm{a}$ & 52.25 & $\mathrm{a}$ \\
\hline Lisophos then Ethrel & 11.68 & fg & 10.72 & fg & 5.98 & fg & 26.57 & defg & 13.74 & $\mathrm{~cd}$ \\
\hline Calcium acetate & 9.62 & fg & 3.65 & fg & 4.03 & fg & 16.62 & $\mathrm{fg}$ & 8.48 & $\mathrm{~d}$ \\
\hline Calcium acetate mixed with Ethrel & 5.75 & fg & 13.38 & fg & 49.11 & bcd & 56.45 & $\mathrm{bc}$ & 31.17 & $\mathrm{bc}$ \\
\hline Calcium acetate then Ethrel & 13.71 & fg & 5.99 & fg & 20.99 & efg & 36.84 & cdef & 19.38 & bcd \\
\hline
\end{tabular}

*Values, within the characteristic, with similar letters were not significantly different according to the means comparison made by using the least significant difference (LSD) at 0.05 levels.

Table 2: The effect of the preharvest treatments, the time factor and their interaction between them on leaf abscission (\%) of 'Valencia' treated orange trees during 2015 season:

\begin{tabular}{|c|c|c|c|c|c|c|c|c|c|c|}
\hline \multirow{2}{*}{$\begin{array}{l}\text { Treatments } \\
\text { Control }\end{array}$} & \multicolumn{2}{|c|}{ After first spray } & \multicolumn{2}{|c|}{ After second spray } & \multicolumn{2}{|c|}{ After third spray } & \multicolumn{2}{|c|}{$\begin{array}{l}\text { Before first spray until } \\
\text { harvest }\end{array}$} & \multirow{2}{*}{\multicolumn{2}{|c|}{$\begin{array}{l}\text { Mean } \\
10.33\end{array}$}} \\
\hline & 1.95 & $i^{*}$ & 3.31 & hi & 20.36 & ghi & 20.20 & fghi & & \\
\hline Lisophos & 8.29 & hi & 5.36 & hi & 32.32 & efghi & 40.69 & def & 21.66 & $\mathrm{~cd}$ \\
\hline Ethrel & 18.66 & ghi & 30.71 & efghi & 86.15 & $\mathrm{ab}$ & 91.30 & $\mathrm{a}$ & 56.70 & $\mathrm{a}$ \\
\hline Lisophos mixed with Ethrel & 33.76 & efgh & 13.50 & ghi & 66.54 & bcd & 80.42 & $\mathrm{ab}$ & 48.55 & $a b$ \\
\hline Lisophos then Ethrel & 13.18 & ghi & 7.12 & hi & 32.78 & efghi & 48.10 & cde & 25.29 & $\mathrm{~cd}$ \\
\hline Calcium acetate & 9.43 & hi & 11.27 & hi & 46.47 & cdef & 55.65 & cde & 30.70 & $\mathrm{bc}$ \\
\hline Calcium mixed with Ethrel & 10.37 & hi & 33.28 & efghi & 52.77 & cde & 71.82 & $a b c$ & 42.06 & $a b c$ \\
\hline Calcium acetate then Ethrel & 11.11 & hi & 9.08 & hi & 53.88 & cde & 62.57 & bcd & 34.16 & bc \\
\hline Mean & 13.35 & $\mathrm{c}$ & 14.20 & $\mathrm{c}$ & 48.35 & $\mathrm{~b}$ & 58.84 & $\mathrm{a}$ & ---- & - \\
\hline
\end{tabular}


spray, still, the application of Lisophos alone had a similar magnitude of leaf abscission to that found in the control trees. That could be attributed to the adverse weather conditions in the second season. Meanwhile, the advanced application of Lisophos had a mitigating effect on leaf abscission, especially following the second and the third sprays followed by the application of Ethrel when preceded by calcium acetate.

The effect of interaction between preharvest applied treatments and the time factor on leaf abscission (\%) between the initial spray and harvest of 'Valencia' orange trees during the two successive seasons 2014 and 2015:

Changes in the magnitude of leaf abscission between the two times of the initial spray and harvest as influenced by their interaction with various applied treatments to 'Valencia' orange trees were reported in Tables (1-2). The data indicated that the normal leaf abscission of the control ranged between 14 to $20 \%$ during the two seasons 2014 and 2015, respectively. However, the application of Ethrel three times on the same labeled branch resulted in a very drastic leaf abscission that ranged between 84 and $91 \%$ for the same two seasons, respectively. Meanwhile, the sole application of Lisophos resulted in similar leaf abscission to that found with the control which did not vary significantly in both seasons. Alleviation of Ethrel damage to sprayed branches of ' Valencia ' treas was achieved when Lisophos treatment preceded the application of Ethrel. However, mixing Lisophos with Ethrel prior to the three sprays had a positive outcome on the reduction of leaf abscission but the results indicated to a further-significant reduction in leaf abscission when Lisophos treatment preceded Ethrel application. Furthermore, the consequence of Ethrel treatment whether it was mixed with calcium acetate or when it preceded Ethrel was similar in the two seasons of the three applications to 'Valencia' branches. Meanwhile, the sole application of calcium acetate had similar influence on leaf abscission when compared with that resulting from the sole application of Lisophos in both seasons.

\section{The effect of preharvest applied treatments on some Physical characteristics of 'Valencia' oranges during 2014 and 2015 seasons:}

The results concerning the effect of Ethrel, Lisophos, calcium acetate alone, calcium acetate when mixed with Ethrel, calcium acetate followed by Ethrel, Lisophos was mixed with Ethrel or Lisophos treatment preceded the application of Ethrel on the fruit weight (gm) of 'Valencia' orange trees during both 2014 and 2015 seasons were listed in Table 3. The data revealed that when Lisophos alone, Lisophos followed by Ethrel and Lisophos mixed with Ethrel were applied, there were no significant changes in fruit weight in both seasons and calcium acetate alone in season two as compared with the control. Furthermore, the data revealed that calcium acetate treatment preceded the application of Ethrel on 'Valencia' oranges had similar fruit weight when compared with the control in both seasons in a consistent manner. Similarly, calcium acetate alone had a significant decrease in fruit weight in the first season as compared with the control. Moreover, the application of Ethrel or calcium acetate mixed with Ethrel significantly reduced orange weight relative to the control in both studied seasons.

Fruit length $(\mathrm{cm})$ of 'Valencia' orange fruits as influenced by various applied treatments was determined and reported in Table 3. The average values of both experimental seasons indicated that Lisophos followed by Ethrel and calcium acetate followed by Ethrel treatments, significantly increased fruit length as compared with Ethrel alone. On the other hand, Lisophos, calcium acetate alone, calcium acetate when mixed with Ethrel or Lisophos mixed with Ethrel did not have a significant effect on fruit length comparing with the control. Meanwhile, Ethrel reduced fruit length when compared with control.

In terms of fruit diameter as affected by various applied treatments at harvest, the data in Table 3 revealed that the control treatment of 'Valencia' orange fruits did not significantly vary from that treated with Lisophos alone, calcium acetate alone, Ethrel alone and calcium acetate mixed with Ethrel. However, the treated fruits with Ethrel followed by calcium acetate had significantly larger fruit diameter than the control in the first season. Meanwhile, there was a non significant reduction in fruit diameter when treated with Ethrel alone or calcium mixed with Ethrel in the 2015 season. Moreover, the application of calcium acetate followed by Ethrel, Lisophos mixed with Ethrel and Lisophos treatment preceded the application of Ethrel did not make a significant difference on fruit 
diameter compared with the control in the second season. Furthermore, the data revealed that either calcium acetate alone or Lisophos alone had similar effect to that of the control in "Valencia" oranges in both seasons.

Changes in 'Valencia' oranges fruit size $\left(\mathrm{cm}^{3}\right)$ as influenced by various applied treatments at harvest were reported in Table 3. The data indicated that both Lisophos mixed with Ethrel and calcium acetate alone had the same effect in their influence on 'Valencia' oranges in both seasons. Moreover, the applications of Lisophos, Lisophos followed by Ethrel and calcium acetate treatment preceded the application of Ethrel did not result in any significant change than the control at harvest in "Valencia" oranges in a consistent manner in both studies seasons. Furthermore, when Ethrel alone was applied, a significant reduction occurred in "Valencia" orange fruit size relative to the application of Lisophos alone or control in both seasons.

Rag weight (gm) of 'Valencia' oranges at harvest as influenced by the applied treatments, it was evident from the data in Table 3 that calcium acetate mixed with Ethrel, calcium acetate alone and Lisophos followed by Ethrel were equally in their influence on 'Valencia' oranges in both seasons when compared with the control and calcium acetate treatment preceded the application of Ethrel in the first season. Meanwhile, Lisophos alone and Lisophos mixed with Ethrel had a significant increase in rag weight in both seasons as compared with Ethrel and calcium acetate followed by Ethrel in 2015 season. On the other hand, when Ethrel applied alone, it was able to mitigate its influence on rag weight comparing with Lisophos alone or Lisophos mixed with Ethrel, but it had no significant reduction in rag weight of 'Valencia' oranges when compared with control in the two seasons.

In terms of flesh weight (gm) of 'Valencia' oranges as affected by various used treatments, the results in Table 3 showed that Lisophos followed by Ethrel and calcium followed by Ethrel didn't result in a significant change in flesh weight in both seasons relative to the control, Lisophos alone and Lisophos mixed with Ethrel in the first season . Moreover, Lisophos alone and Lisophos mixed with Ethrel led to a significant reduction in flesh weight of 'Valencia' oranges, especially in the second season. Meanwhile, when Ethrel alone was applied, there was a significant reduction in flesh weight followed by calcium mixed with Ethrel, then calcium alone when compared with the control in both seasons.

\section{The effect of preharvest applied treatmenta on some Chemical characteristics of "Valencia' oranges during 2014 and 2015 seasons.}

The data of total soluble solids (TSS) \% as influenced by various treatments to 'Valencia' orange fruits at harvest was reported in Table 4. The data showed that TSS was not significantly affected by any of the individual application such as Lisophos, calcium acetate or Ethrel relative to the control, in both seasons. Meanwhile, it was found that there was no influence on TSS content in the fruit with the treatment of calcium mixed with Ethrel as compared with control in a consistent manner in both studied seasons. On the other hand, Lisophos treatment when preceded the application of Ethrel significantly reduced the TSS content in the fruit when compared with the control. Furthermore, Lisophos was mixed with Ethrel and calcium acetate followed by Ethrel treatments were able to make a significant reduction of the TSS content when compared with the control in both seasons.

The influence of various applied treatments during the two seasons on juice acidity \% of 'Valencia' orange fruits was shown in Table 4. The data proved that Ethrel treatment caused a significant reduction in juice acidity when compared with the control in both seasons followed by Lisophos mixed with Ethrel and calcium mixed with Ethrel in 2015 season. However, Lisophos alone did not alter juice acidity since it was similar to that found in the control in both seasons. Furthermore, Lisophos when preceded the application of Ethrel did not result in any significant change in acidity at harvest in 'Valencia' oranges in a consistent manner in both seasons comparing with the control. Meanwhile, the application of either calcium acetate alone or followed by Ethrel did not make any significant change in juice acidity as compared with the control. On the other hand, when calcium acetate or Lisophos plus Ethrel application were able to mitigate their influence on juice acidity when compared with the control in the second season.

The effect of applied treatments during the two seasons of study on L-ascorbic acid content (mg/ $100 \mathrm{ml}$ juice) of 'Valencia' orange was reported in Table 4. The data decleared that the application of Ethrel alone or calcium mixed with Ethrel caused a significant reduction of ascorbic acid content in 
Table 3: Physical characteristics of 'Valencia' orange fruits as influenced by various preharvest applied treatments during the two seasons 2014 and 2015 :

\begin{tabular}{|c|c|c|c|c|c|c|c|c|c|c|c|c|}
\hline \multirow[t]{2}{*}{ Treatments } & \multicolumn{2}{|c|}{$\begin{array}{c}\text { Fruit weight } \\
\text { (gm) }\end{array}$} & \multicolumn{2}{|c|}{$\begin{array}{l}\text { Fruit length } \\
\text { (cm) }\end{array}$} & \multicolumn{2}{|c|}{$\begin{array}{c}\text { Fruit } \\
\text { diameter(cm) }\end{array}$} & \multicolumn{2}{|c|}{$\begin{array}{c}\text { Fruit size } \\
\left(\mathrm{cm}^{3}\right)\end{array}$} & \multicolumn{2}{|c|}{$\begin{array}{l}\text { Rag weight } \\
\text { (gm) }\end{array}$} & \multicolumn{2}{|c|}{$\begin{array}{c}\text { flesh weight } \\
\text { (gm) }\end{array}$} \\
\hline & 2014 & 2015 & 2014 & 2015 & 2014 & 2015 & 2014 & 2015 & 2014 & 2015 & 2014 & 2015 \\
\hline Control & $197.78 \mathrm{a}^{*}$ & $203.3 \mathrm{a}$ & $6.57 \mathrm{ab}$ & $6.65 \mathrm{abc}$ & $6.05 \mathrm{bc}$ & $6.37 \mathrm{a}$ & $210.75 \mathrm{a}$ & $208.7 \mathrm{a}$ & $36.17 \mathrm{~b}$ & $32.63 b$ & $161.61 \mathrm{a}$ & $170.73 a$ \\
\hline Lisophos & $180.35 \mathrm{ab}$ & $195.1 \mathrm{ab}$ & $6.44 \mathrm{bc}$ & $6.62 \mathrm{abc}$ & $6.01 \mathrm{bcd}$ & $6.33 \mathrm{a}$ & $201 \mathrm{ab}$ & $196.3 \mathrm{ab}$ & $42.36 \mathrm{a}$ & & $137.99 \mathrm{ab}$ & $147.77 \mathrm{bc}$ \\
\hline Ethrel & $167.48 \quad \mathrm{~B}$ & $153.30 \mathrm{c}$ & $5.93 \mathrm{c}$ & $5.99 \mathrm{~d}$ & $5.97 \mathrm{bcd}$ & $5.83 \mathrm{~b}$ & $186.00 \mathrm{~cd}$ & $157.50 \mathrm{c}$ & $35.01 \mathrm{~b}$ & $31.90 \mathrm{~b}$ & $132.47 b$ & $121.40 \mathrm{~d}$ \\
\hline $\begin{array}{l}\text { Lisophos mixed } \\
\text { with Ethrel }\end{array}$ & $186.27 \mathrm{ab}$ & $191.25 \mathrm{ab}$ & $6.65 \mathrm{ab}$ & $6.35 \mathrm{bcd}$ & $6.26 \mathrm{ab}$ & $6.12 \mathrm{~b}$ & $189.75 b c$ & $182.4 \mathrm{~b}$ & $42.52 \mathrm{a}$ & $44.67 \mathrm{a}$ & $143.75 \mathrm{ab}$ & $146.57 \mathrm{bc}$ \\
\hline $\begin{array}{l}\text { Lisophos then } \\
\text { Ethrel }\end{array}$ & $182.73 \mathrm{Ab}$ & $195.10 \mathrm{ab}$ & $6.97 \mathrm{a}$ & $7.03 \mathrm{a}$ & $5.54 \mathrm{~d}$ & $6.41 \mathrm{a}$ & $200.5 \mathrm{abc}$ & $200.7 \mathrm{ab}$ & $36.79 \mathrm{ab}$ & $40.45 \mathrm{ab}$ & $145.93 \mathrm{ab}$ & $154.65 \mathrm{abc}$ \\
\hline Calcium acetate & $167.99 b$ & $190.05 \mathrm{ab}$ & $6.35 \mathrm{bc}$ & $6.32 \mathrm{~cd}$ & $5.93 \mathrm{bcd}$ & $6.17 \mathrm{ab}$ & $187.75 b c$ & $185.45 b$ & $40.12 \mathrm{ab}$ & $40.15 \mathrm{ab}$ & $127.87 \mathrm{~b}$ & $149.90 \mathrm{bc}$ \\
\hline $\begin{array}{l}\text { Calcium mixed } \\
\text { with Ethrel }\end{array}$ & $166.67 b$ & $175.35 \mathrm{bc}$ & $6.28 \mathrm{bc}$ & $6.25 \mathrm{~cd}$ & $5.61 \mathrm{~cd}$ & $5.97 \mathrm{~b}$ & $172.50 \mathrm{~d}$ & $182.70 \mathrm{~b}$ & $36.01 \mathrm{ab}$ & $39.25 \mathrm{ab}$ & $130.66 \mathrm{~b}$ & $136.10 \mathrm{~cd}$ \\
\hline $\begin{array}{l}\text { Calcuim then } \\
\text { Ethrel }\end{array}$ & $201.46 \mathrm{a}$ & $200.60 \mathrm{a}$ & $7.07 \mathrm{a}$ & $6.79 \mathrm{ab}$ & $6.66 \mathrm{a}$ & $6.12 \mathrm{ab}$ & $201.00 \mathrm{ab}$ & $197.65 \mathrm{ab}$ & $39.95 \mathrm{ab}$ & $42.30 \mathrm{a}$ & $161.51 \mathrm{a}$ & $158.30 \mathrm{ab}$ \\
\hline
\end{tabular}

*Values, within the characteristic, with similar letters were not significantly different according to the means comparison made by using the least significant difference (LSD) at 0.05 levels.

Table 4: Chemical characteristics of 'Valencia' orange fruits as influenced by various applied pre-harvest treatments during the two seasons 2014 and 2015 :

\begin{tabular}{|c|c|c|c|c|c|c|c|c|c|c|c|c|c|c|}
\hline \multirow{2}{*}{ Treatments } & \multicolumn{2}{|c|}{$\begin{array}{c}\text { T.S.S } \\
\%\end{array}$} & \multicolumn{2}{|c|}{$\begin{array}{c}\text { Acidity } \\
\%\end{array}$} & \multicolumn{2}{|c|}{$\begin{array}{l}\text { L-ascorbic acid } \\
(\mathrm{mg} / 100 \mathrm{ml})\end{array}$} & \multicolumn{2}{|c|}{ Total sugar $\%$} & \multicolumn{2}{|c|}{$\begin{array}{c}\text { Chlorophyll A } \\
\text { (mg/100 g) }\end{array}$} & \multicolumn{2}{|c|}{$\begin{array}{c}\text { Chlorophyll B } \\
\text { (mg/100 g) }\end{array}$} & \multicolumn{2}{|c|}{$\begin{array}{l}\text { Carotene } \\
(\mathrm{mg} / 100 \mathrm{~g})\end{array}$} \\
\hline & 2014 & 2015 & 2014 & 2015 & 2014 & 2015 & 2014 & 2015 & 2014 & 2015 & 2014 & 2015 & 2014 & 2015 \\
\hline Control & $14.50 \mathrm{a}^{*}$ & $14.90 \mathrm{a}$ & $1.61 \mathrm{a}$ & $1.03 a$ & $36.25 \mathrm{a}$ & $41.25 \mathrm{a}$ & $9.54 b c$ & $9.69 b c$ & $2.46 a$ & $2.83 a$ & $2.38 \mathrm{a}$ & $1.71 \mathrm{ab}$ & $0.97 \mathrm{~d}$ & $0.56 \mathrm{c}$ \\
\hline Lisophos & $14.20 \mathrm{ab}$ & $14.57 \mathrm{a}$ & $1.63 \mathrm{a}$ & $1.10 \mathrm{a}$ & $33.13 b c$ & $39.63 \mathrm{ab}$ & $9.83 \mathrm{ab}$ & 9.94ab & $1.61 \mathrm{~b}$ & $2.57 \mathrm{a}$ & $1.56 \mathrm{~b}$ & $1.97 \mathrm{a}$ & $0.78 \mathrm{~d}$ & $0.88 \mathrm{bc}$ \\
\hline Ethrel & $14.35 \mathrm{a}$ & $14.4 \mathrm{ab}$ & $1.21 \mathrm{~b}$ & $0.92 \mathrm{c}$ & $30.25 \mathrm{c}$ & $35.13 \mathrm{c}$ & $9.88 \mathrm{ab}$ & $10.28 \mathrm{a}$ & $0.77 b c$ & $0.65 \mathrm{~d}$ & $0.75 c$ & $0.32 \mathrm{c}$ & $1.91 \mathrm{a}$ & $1.76 \mathrm{a}$ \\
\hline $\begin{array}{l}\text { Lisophos mixed } \\
\text { with Ethrel }\end{array}$ & $12.85 \mathrm{c}$ & $13.87 \mathrm{c}$ & $1.46 \mathrm{ab}$ & $0.95 b c$ & $34.37 \mathrm{ab}$ & $40.45 \mathrm{a}$ & $9.04 d$ & $9.36 \mathrm{c}$ & $0.80 \mathrm{bc}$ & $2.32 \mathrm{ab}$ & $0.54 \mathrm{c}$ & $1.49 \mathrm{ab}$ & $1.53 \mathrm{bc}$ & $0.66 \mathrm{bc}$ \\
\hline $\begin{array}{l}\text { Lisophos then } \\
\text { Ethrel }\end{array}$ & $13.35 \mathrm{bc}$ & $13.95 \mathrm{bc}$ & $1.54 \mathrm{ab}$ & $1.02 \mathrm{ab}$ & $35.75 \mathrm{ab}$ & $39.63 \mathrm{ab}$ & $9.16 \mathrm{~d}$ & $9.67 \mathrm{bc}$ & $0.69 \mathrm{c}$ & $2.18 \mathrm{ab}$ & $0.43 \mathrm{c}$ & $0.99 \mathrm{bc}$ & $1.35 \mathrm{c}$ & $1.05 \mathrm{bc}$ \\
\hline Calcium acetate & $14.55 \mathrm{a}$ & $14.45 \mathrm{ab}$ & $1.43 \mathrm{ab}$ & $1.04 \mathrm{a}$ & $35.37 \mathrm{ab}$ & $38.90 \mathrm{ab}$ & $9.97 \mathrm{a}$ & $9.96 \mathrm{ab}$ & $0.62 \mathrm{c}$ & $2.13 \mathrm{ab}$ & $0.61 \mathrm{c}$ & $1.22 \mathrm{ab}$ & $1.53 \mathrm{bc}$ & $1.08 \mathrm{bc}$ \\
\hline $\begin{array}{l}\text { Calcium mixed } \\
\text { with Ethrel }\end{array}$ & $14.50 \mathrm{a}$ & $14.40 \mathrm{ab}$ & $1.41 \mathrm{ab}$ & $0.95 b c$ & $31.13 \mathrm{c}$ & $37.50 \mathrm{bc}$ & $9.69 \mathrm{ab}$ & $10.09 \mathrm{ab}$ & $0.53 \mathrm{c}$ & $0.82 \mathrm{~cd}$ & $0.53 \mathrm{c}$ & $0.31 \mathrm{c}$ & $1.73 \mathrm{ab}$ & $1.79 \mathrm{a}$ \\
\hline $\begin{array}{l}\text { Calcuim then } \\
\text { Ethrel }\end{array}$ & $12.60 \mathrm{c}$ & $13.77 \mathrm{c}$ & $1.40 \mathrm{ab}$ & $1.08 \mathrm{a}$ & $37.20 \mathrm{a}$ & $40.25 \mathrm{a}$ & $9.24 \mathrm{~cd}$ & $10.25 \mathrm{a}$ & $0.85 b c$ & $1.67 \mathrm{bc}$ & $0.39 \mathrm{c}$ & $1.08 \mathrm{bc}$ & $1.36 \mathrm{c}$ & $1.21 \mathrm{ab}$ \\
\hline
\end{tabular}

Ethrel

*Values, within the characteristic with similar letters were not significantly different according to the means comparison made by using the least significant difference (LSD)

at 0.05 levels. 
relative to the control in both seasons and Lisophos alone in the 2014 season. All treatments expect those mentioned above were equally in their effect on L-ascorbic acid and had a similar effect to that of the control in both seasons.

The response of total sugars percentage in fruit juice of 'Valencia' oranges to various treatments was reported in Table 4. It was obvious that there was a significant increase in total sugars content with the treatments of calcium acetate as compared with control in the first season. Meanwhile, calcium mixed with Ethrel application was effective on rising total sugars (\%) non significantly comparing with the control in both seasons as well as calcium followed by Ethrel had the same effect in the second season. Even though, the application with Lisophos mixed with Ethrel and Lisophos treatment preceded the application of Ethrel resulted in a decrease of the total sugars content in 'Valencia' orange fruits relative to the control in 2014 season.

The data of chlorophyll A content (mg / $100 \mathrm{~g}$ ) of 'Valencia' oranges as influenced by various treatments was shown in Table 4. It indicated that control treatment possessed the highest chlorophyll a content among all other treatments followed by Lisophos alone in both studied seasons. The highest significant reduction in chlorophyll a at harvest was found in calcium mixed with Ethrel as compared with the control lin 2014 season. Similar trend of results was obtained with calcium acetate in the same season. In a similar manner, Ethrel alone resulted in the lowest chlorophyll a content among all other treatments in the second season. Meanwhile, the application of Lisophos when followed with Ethrel, Lisophos mixed with Ethrel and calcium acetate did not cause a significant alteration in chlorophyll a content compared to the control in the 2015 season. However, Lisophos mixed with Ethrel, calcium acetate followed by Ethrel and Ethrel made a significant alteration in chlorophyll a content relative to the control in the first season and calcium acetate mixed with Ethrel and calcium acetate treatment preceded the application of Ethrel in the second season.

The response of chlorophyll B content (mg/ 100g) of 'Valencia' oranges at harvest was reported in Table 4. The data revealed that control treatment retained the highest chlorophyll $b$ content among all other treatments followed by Lisophos alone in the 2014 season. Otherwise, In the 2015 season, Lisophos alone resulted in the highest chlorophyll $\mathrm{b}$ content among all other treatments followed by control. Chlorophyll $\mathrm{b}$ at fruit rind was not significantly influenced by Lisophos when mixed with Ethrel treatment or calcium acetate alone relative to the control in the 2015 season. Thus, in general, all individual treatments, even the combination ones and calcium acetate followed by Ethrel were able to reduce chlorophyll $b$ content of 'Valencia' oranges in the first season. However, the application of either Lisophos or calcium acetate followed by Ethrel was able to significantly change chlorophyll $b$ content in the 2015 season as compared with the control. In a similar manner, calcium acetate followed by Ethrel treatment led to the lowest chlorophyll $b$ content among all other treatments in the first season, but in the second season was calcium acetate mixed with Ethrel.

The influence of various treatments on the content of carotene $(\mathrm{mg} / 100 \mathrm{~g})$ in 'Valencia' orange rind was shown in Table 4 . The highest significant increase in carotene was found with the application of Ethrel alone or calcium acetate mixed with Ethrel as compared with the control in both seasons, in addition to calcium acetate followed by Ethrel in the 2015 season. However, Lisophos mixed with Ethrel, Lisophos treatment when preceded the application of Ethrel and calcium acetate alone had a significant alteration in carotene content relative to the control in both seasons and calcium acetate followed by Ethrel in the 2014 season. On the other hand, control treatment in general possessed the lowest carotene content among all other treatments in the 2015 season. Otherwise, In the 2014 season, Lisophos alone treatment resulted in the lowest carotene content among all other applied treatments followed by control.

\section{Discussion}

The present study provided evidence about the possibility of mitigating and alleviating the damage of Ethrel to fruit trees when sprayed for the purpose of accelerating carotene formation in the fruits before harvest while reducing leaf abscission, especially mature leaves that work as a source of carbohydrates to many sinks such as buds, fruits, branches and even roots. The release of ethylene from penetrated-sprayed Ethrel causes the breakdown of chlorophyll and the stimulation of carotene formation in the tissue, juice and rind. However, it stimulates some cell wall hydrolyzing enzyms such as polygalacturonase cellulases and pectin methylesterases. The outcome of such activation is the increase of fruit and leaf abscission, especially with the rise of temperature during the day in many 
citrus production areas around the world. It has been reported that LPE (Lisophos as the commercial name) can inhibit ethylene production at relatively high concentration (Farag and Palta, 1991).

Meanwhile, LPE was able to inhibit the activity of the cell wall hydrolyzing enzyme called polygalacturonase ( Farag and Palta, 1992). Moreover, lysophosphatidylethanolamine proved to be able to delay tissue senescence whether in the leaves or fruits and to reduce the leakage of electrolytes which prolonged the fruit storability and shelf life ( Farag and Palta, 1993a). On the other hand, exposure of 'Valencia' orange trees to multiple stresses after maturity such as heat, salinity, chemical stress from sprayed pesticide can lead to more leaf abscission during that period of time. Use of the Lisophos was found to mitigate the negative effects of such stresses as reported in its granted patent by the USA Patent Office ( Farag et al., 2003). Thus the advanced addition of Lisophos to 'Valencia' trees, in this study, was able to alleviate the effects of many stresses as well as the adverse effects of ethylene that was generated by Ethrel spray when was preceded by Lisophos application. The results of electrolyte leakage after cold storage further supported the role of Lisophos since it was able to reduce the leakage from the rind membrane when compared with the control. Lisophos (LPE) was reported to protect the structure of the plasma membrane (Farag, 1989), which reflected on increasing the vigor of plant tissues including leaves and fruits and delaying senescence (Farag and Palta, 1993b).

Meanwhile, the application of calcium, especially in the form of calcium acetate was reported to mitigate the adverse effect of ethylene on plant tissue (Sonkar and Ladaniya, 1999). In this study, when calcium acetate mitigated the adverse effect of Ethrel, it was more effective on reducing leaf abscission which could be attributed to the effect of calcium on the ligationor binding the cell wall polymers or to the effect of calcium on maintaining the integrity of the plasma membrane by binding to the polar heads which reflected on healthful leaf and fruit cell (Liegeois et al., 1995). This could explain the reason behind the advanced addition of calcium as compared with the mixing effect with an-ethylene releasing compound, namely Ethrel.

\section{References}

Ahmed, W. and R. Azmat, 2019. Citrus: An Ancient Fruits of Promise for Health Benefits. In CitrusHealth Benefits and Production Technology. IntechOpen.

Alferez. F. L and J. K. Burns, 2006. Physiological changes associated with senescence and abscission in mature citrus fruit induced by 5-chloro-3-methyl-4-nitro-1H-pyrazole and ethephon application. Physiologia Plantarum, 127: 66-73.

A. O. A. C., 1985. Official Methods of Analysis of the Association of Official Analytical Chemists. Washington DC., USA., 14 Th Ed.

Enejoh, O. S., I. O. Ogunyemi, M. S. Bala, I. S. Oruene, M. M. Suleiman, and S. F. Ambali, 2015. Ethnomedical Importance of Citrus Aurantifolia (Christm) Swingle. The Pharma Innovation, 4(8, Part A), 1.

Farag, K.M., 1989. Enhancing effectiveness of ethephon under field conditions by modifying cuticular transport properties and by stimulating ethylene production in cranberry fruit. $\mathrm{PhD}$ Diss.,Univ. Wisconsin, Madison

Farag, K. M. and J. P. Palta, 1991. Use of Lyso-phosphatidylethanolamine, a natural lipid, as an aid for fruit ripening and improving keeping quality. In: Proc.17th Ann. Meeting Pl. Growth Reg. Soc. Amer., pp. 135-137.

Farag, K.M. and J.P. Palta, 1992. Evidence for a specific inhibition of the activity of polygalacturonase by lysophosphatidylethanolamine in tomato fruit tissue: Implication for enhancing storage stability and reducing abscission of the fruit. Plant Phys., 99:54 (Abstr.).

Farag, K. M. and J. P. Palta, 1993a. Use of natural lipids to accelerate ripening and enhance storage life of tomato fruit with and without ethephon. Hort. Tech., 3: 62-65.

Farag, K. M. and J. P. Palta, 1993b. Use of Lyso-phosphatidylethanolamine, a natural lipid, to retard tomato leaf and fruit senescence. Pl. Phys., 87: 515-524.

Farag, K.M., J.P. Palta and S.B. Ryu, 2003. Methods for enhancing plant health, protecting plants from biotic and abiotic stress related injuries and enhancing the recovery of plants injured as a result of such stresses United States Granted Patent number: 6559099 
Farag, K.M. and N. M. Nagy, 2018. Preharvest treatments to enhance "Keitt" mangoes ripening and to extend their shelf life. Hort. Sci. and Ornamental Plants 10 (1): 41-52, ISSN 2079-2158

FAOSTAT, 2017. Food and Agriculture Organization of the United Nations Statistics Division. Internet site available at http://faostat3.fao. Org

Fujii, H., T. Shimada, A. Sugiyama, F. Nishikawa, T. Endo, M. Nakano and M. Omura, 2007. Profiling ethylene-responsive genes in mature mandarin fruit using a citrus $22 \mathrm{~K}$ oligoarray. Plant Sci., 173(3): 340-348.

Iwahori, S. and J. T. Oohata, 1981. Effects of 2-chloroethyl phosphonic acid and calcium acetate on defoliation and fruit drop, and degreening of "Ponkan" fruit. Mem. Kagoshima Uni. Res. Center S. Pac., 2: 67- 73 .

Krajewski, A., 1997. Guidelines for the improvement of fruit colour in citrus, In: Von Broembsen, L.A. (ed.). Outspan International, Centurion, South Africa, p. 1-25.

Lichtenthaler, H. K. and A. R. Wellburn, 1985. Determination of total carotenoids and chlorophylls a and $b$ of leaf in different solvents, Biol. Soc. Trans., 11: 591-592.

Liegeois, S., J. Pons, M. Juan, V. Almela, and M. Agusti, 1995. Effects of various treatments on the maturation process in Marisol mandarin (Citrus reticulata Blanco). Fruits, 50(2): 117-124.

Rafiq, S., R. Kaul, S. A. Sofi, N. Bashir, F. Nazir and G. A. Nayik, 2018. Citrus peel as a source of functional ingredient: a review. J. Saudi Soc. Agri. Sci., 17(4):351-358.

Snedecor, G. W. and W. G. Cochran, 1980. Statistical Methods. 6th Ed. Iowa State Univ. Press, Ames, Iowa. USA.

Smith, F., 1956. Colorimetric method for determination of sugar and related substance. Analytical Chemistry, 28: 350-356.

Sonkar, R. K. and M. S. Ladaniya, 1999. Effect of pre-harvest sprays of ethephon, calcium acetate and carbendazim on rind color, abscission and shelf-life of "Nagpur" mandarin (Citrus reticulata). Indian J. Agri. Sci. 69(2): 130-135. 